\title{
Effect of plasma nitriding process on the fatigue and high temperature corrosion resistance of Inconel $740 \mathrm{H}$ nickel alloy
}

\author{
Mateusz Kopec ${ }^{1,2}\left(\right.$ Dominika Gorniewicz $^{3} \cdot$ Dominik Kukla $^{1} \cdot$ Izabela Barwinska ${ }^{1}$. Stanisław Jóźwiak ${ }^{3}$. \\ Ryszard Sitek ${ }^{4}$. Zbigniew L. Kowalewski ${ }^{1}$
}

Received: 6 October 2021 / Revised: 1 January 2022 / Accepted: 12 January 2022 / Published online: 28 January 2022

(c) The Author(s) 2022

\begin{abstract}
The paper presents a comparison of microhardness, fatigue and high temperature corrosion of Inconel $740 \mathrm{H}$ nickel alloy in its as-received state and the same material with nitrided surface layers. The nitrided layers were produced using traditional glow discharge nitriding (specimens nitriding on the cathode potential) and an active screen (specimens nitriding at the plasma potential). A microstructure of the layers was characterized through the scanning electron microscopy, X-ray energy dispersive spectroscopy and X-ray diffraction analysis. Mechanical properties of the nitrided Inconel 740H alloy were examined using microhardness measurements and standard fatigue tests. It was found that Inconel $740 \mathrm{H}$ with a nitrided surface exhibited an improved fatigue response of $50 \mathrm{MPa}$ in the whole range of stress amplitudes from 350 to $650 \mathrm{MPa}$ and almost $325 \%$ increase of hardness for plasma modified surface and $250 \%$ for cathode modified surface. Additionally, the application of cathode nitriding enhanced the corrosion resistance of the alloy in question and effectively protected it against a high temperature oxidation.
\end{abstract}

Keywords Nitriding $\cdot$ Nickel alloys $\cdot$ Coatings $\cdot$ Fatigue $\cdot$ Corrosion

\section{Introduction}

Inconel $740 \mathrm{H}$ is an austenitic nickel-chromium-based superalloy, which is well suited for service under extreme conditions (pressure and heat) due to its superior oxidationcorrosion-resistance related to its microstructure strengthened with $\gamma^{\prime}$ phase and alloying elements such as cobalt and molybdenum. Additionally, a high content of the chromium ensures its oxidation resistance in a vapor water environment and temperature up to $750{ }^{\circ} \mathrm{C}$ which results from the formation of chromium oxide $\mathrm{Cr}_{2} \mathrm{O}_{3}$ scale. Such properties and high pressure resistance (up to $35 \mathrm{MPa}$ ) made Inconel $740 \mathrm{H}$ an ideal candidate for application in the aggressive environments, such as steam cycles [1]. A supplementary feature, that distinguishes Inconel $740 \mathrm{H}$ from the other nickel-based alloys is its increased creep resistance due to its homogeneous chemical composition. Unlike a majority of superalloys, this alloy does not have TCP phases that significantly reduces a strength of the materials. Therefore, the precipitation-strengthened Inconel $740 \mathrm{H}$ is suitable for

Zbigniew L. Kowalewski

zkowalew@ippt.pan.pl

1 Institute of Fundamental Technological Research, Polish Academy of Sciences, Pawińskiego 5B, 02-106 Warsaw, Poland

2 Department of Mechanical Engineering, Imperial College London, London SW7 2AZ, UK

3 Faculty of Advanced Technologies and Chemistry, Military University of Technology, 00-908 Warsaw, Poland

4 Faculty of Materials Science and Engineering, Warsaw University of Technology, Wołoska 141, 02-507 Warsaw, Poland 
applications in the advanced ultra-supercritical (A-USC) power plants with the steam conditions of $750{ }^{\circ} \mathrm{C} / 35 \mathrm{MPa}$ and supercritical $\mathrm{CO}_{2}$ feed systems. As a consequence, it can significantly reduce a boiler production costs using thinner walls [2]. It should be mentioned, that materials dedicated to the superheater/reheater should have an outstanding oxidation resistance. According to the literature, $60 \%$ of boiler failures occurred due to the steam oxidation and coal-ash corrosion [5]. Among the main reasons of the nickel-based alloys failure due to a high temperature corrosion, one can indicate a loss of the surface strength, crack initiation, dealloying and component failure [6]. Such mechanisms are associated with the occurrence of specific oxides: $\mathrm{Cr}_{2} \mathrm{O}_{3}$, $\mathrm{NiCr}_{2} \mathrm{O}_{4}$, and $\mathrm{NiFe}_{2} \mathrm{O}_{4}$ (Inconel 718) [7], $\mathrm{Cr}_{2} \mathrm{O}_{3}$ and $\mathrm{NiCr}_{2} \mathrm{O}_{4}$ (Inconel 625) [8], $\mathrm{NiCr}_{2} \mathrm{O}_{4}, \mathrm{Cr}_{2} \mathrm{O}_{3}$ and $\mathrm{TiO}_{2}$ (Inconel 625 [9] and Inconel $740 \mathrm{H}[10])$. However, the oxidation behaviour and its mechanism for the nitrided Inconel $740 \mathrm{H}$ nickel alloy at $1000{ }^{\circ} \mathrm{C}$ were not investigated as yet.

Plasma nitriding belongs to the thermo-chemical treatments, that improve the surface properties of materials. It is performed under high voltage conditions and reduced nitrogen pressure up to $10^{-2} \mathrm{~Pa}$. Traditional glow discharge nitriding processes are performed at the cathode potential, where the nitrided element is the cathode. In such case, the edge effect has a significant impact on the diffusion and nucleation of the new phase as the oxide layer from the surface of the workpieces is removed in the first stage of the process. However, the main problems associated to this process is the production of homogeneous layers on elements of complex shapes and sharp edges or small holes. In a large part of these areas, the edge effect causes a change in thickness of the nitrided layer. To eliminate the edge effect, glow-discharge nitriding is used in a pulsed plasma or at the plasma potential, using active screens that enable the formation of a homogeneous nitride layer on the entire surface of the workpiece. The proper selection of the process parameters enables to obtain a coating with the assumed structure, properties and a continuous zone of nitrides or the diffusion zone itself [11]. Plasma nitriding significantly increases the hardness of the surface, which leads to an improvement of the tribological wear resistance. Additionally, compressive stress components in the near-surface zone enhancing the fatigue strength of the element. The reduction of cycle time, relatively low temperature $\left(450-550{ }^{\circ} \mathrm{C}\right)$ and pore-free surface $[12,13]$ are the other advantages distinguishing this process over the conventional methods for surface modification. Plasma nitriding can improve the hardness and wear resistance of many materials being applied in the automotive and aviation industry including aluminium [14] and titanium alloys [15]. Aluminium alloys are widely used in the production of cars and their suspensions to reduce their weight and subsequently decrease $\mathrm{CO}_{2}$ emissions. Despite the high strength-to-weight ratio, these materials have a low resistance to tribological wear. Surface treatments processes such as plasma nitriding enable to obtain high surface hardness and improved wear resistance. Other light-weight materials characterized by a high strength and corrosion resistance are titanium alloys, however, at rapid wear. A number of advantages of these materials make them attractive candidates for the aviation, automotive and biomedicine. Plasma nitriding is often used to increase the tribological properties of titanium alloys leading simultaneously to a reduction of mechanical strength due to formation of the brittle layers and unfavourable microstructural changes [16]. The wear resistance tests are also carrying out on the plasma nitrided nickel alloys. The results captured after conducting the pin-on-disk tests on the Inconel 718 alloy allow to conclude, that for longer duration of the plasma nitriding process duration, the enhanced tribological properties can be obtained [17]. Better wear resistance is associated to increased thickness, roughness and hardness of the CrN layer formed [18]. Nickelbased alloys, due to their superior properties, are widely used for elements operating in the extreme environments. However, despite an excellent high temperature resistance, they are characterized by the reduction of fatigue strength [19]. The occurrence of high vibrations during the operation of elements requires from the materials not only the high static strength, but also, a good fatigue resistance [20]. The extensive application of the nickel-based alloys for gas turbines and different elements working in the aviation and power engineering enforce to find a new techniques to improve their fatigue properties [25], especially during a high temperature performance [21]. Although the positive effect of nitriding on fatigue strength was reported for steels [22] and titanium alloys [23], only a limited data can be found for the nickel superalloys. Moreover, the research on corrosion resistance of the Inconel $740 \mathrm{H}$ nickel superalloy with a $\mathrm{CrN}$ layer produced in the process of impulse plasma nitriding [24] showed, that the $\mathrm{CrN}, \mathrm{Cr}_{2} \mathrm{~N}$ layer of $4.5 \mu \mathrm{m}$ thick functions as an inhomogeneous cathodic coating, which in chloride environments $(0.1 \mathrm{NaCl}+\mathrm{H})$ intensifies pitting corrosion of the material. In chloride-less environments $\left(0.1 \mathrm{M} \mathrm{Na}_{2} \mathrm{SO}_{4}\right)$, the nitride layer does not affect substantially the rate of the alloy corrosion.

Hence, the plasma nitriding technology was proposed in this paper to enhance the fatigue response and high temperature corrosion resistance of Inconel $740 \mathrm{H}$. The material was subjected to cyclic loading to determine its fatigue behaviour under a wide range of stress amplitudes. Subsequently, the heat resistance of Inconel $740 \mathrm{H}$ with a modified surface was investigated during exposure to $1000^{\circ} \mathrm{C}$ for $100 \mathrm{~h}$ in an air atmosphere. A microstructure evolution of the nitrided surface was monitored using scanning electron microscopy (SEM), and subsequently analysed, to provide a deeper understanding of the oxidation behaviour of Inconel $740 \mathrm{H}$ with modified surface due to nitriding. 


\section{Materials and methods}

Inconel $740 \mathrm{H}$ of the chemical composition presented in Table 1 was investigated in this research. The specimens were firstly machined in a Computer Numerical Control (CNC) lathe machine to ensure surface finish. Then, they were subjected to glow discharge nitriding process (Fig. 1a) in two different states of potential: the cathode and plasma potential (active screen), however, under the same conditions, i.e., nitrogen-hydrogen atmosphere $\left(25 \%-\mathrm{N}_{2}+75 \%-\mathrm{H}_{2}\right)$ at $570{ }^{\circ} \mathrm{C}$ for $8 \mathrm{~h}$.

Fatigue tests were performed on the MTS 858 testing machine, with an axial force range of $\pm 25 \mathrm{kN}$ and twisting moment range of $\pm 200 \mathrm{Nm}$, controlled by a TestStar II using such software as TestWare-SX v. 4.0D and 790.20 Fatigue Test Application. The fatigue tests were force controlled with zero mean level and a constant stress amplitude with a frequency of $20 \mathrm{~Hz}$ in the range of stress amplitude from \pm 350 to $\pm 650 \mathrm{MPa}$. A geometry of the fatigue specimen is presented in Fig. 1b. The MTS 634.31F-24 transverse extensometer with a gauge of $10 \mathrm{~mm}$ was calibrated to strain measurement in the range of $0 \div 0.1 \mathrm{~mm} / \mathrm{mm}$ and $0 \div 0.3 \mathrm{~mm} / \mathrm{mm}$. Before testing of the specimens from each successive series, the extensometer was calibrated and the test parameters were optimized for a single specimen from the series. Microhardness measurements were performed at the Vickers method and Schimadzu HMV-G hardness tester using loading force of $50 \mathrm{gf}(0.49 \mathrm{~N})$ for a dwell time of $10 \mathrm{~s}$. Six cathode and six plasma surface modified specimens in the form of $6.5 \mathrm{~mm} \times 6.5 \mathrm{~mm} \times 4 \mathrm{~mm}$ cuboids with initial weight of $1.3 \mathrm{~g}$ were subjected to the heat resistance test at $1000{ }^{\circ} \mathrm{C}$ for $100 \mathrm{~h}$ in air atmosphere. Each specific specimen was removed from the furnace after 1, 5, 15, 20, 50 and $100 \mathrm{~h}$ to measure its weight and dimensions using precise micrometer screw gauge and laboratory scale, respectively. In the next step, the microstructural analysis was performed using Quanta 3D FEG field emission scanning electron microscope (SEM) and Nikon ECLIPSE MA-200 optical microscope (OM). An effect of the heat treatment scale of specimen on its surface for modified and unmodified sections was analysed on grounded and mechanically polished cross sections using SEM operated at $20 \mathrm{kV}$ with energydispersive X-ray spectroscopy (EDS) detector. Such detector was also used to perform a qualitative chemical composition analysis. The phase structure of the base material was determined using the X-ray diffraction method in the $2 \Theta$ system, while the phase composition of the nitrided layer was analyzed by the grazing incidence X-ray diffraction (GI XRD) technique based on the $\mathrm{Co} K \alpha_{1}$ radiation $(\lambda=1.78892 \AA)$ applying a Rigaku Ultima IV system with parallel beam mode of radiation. An oxidation kinetics was determined by mass gain and measurements of the scale after a specific time of the heat treatment. The thickness (width) of diffusion zone was determined by the increased content of aluminium and was measured during SEM observations.

Table 1 Chemical composition of Inconel $740 \mathrm{H}$ in the as-received state

\begin{tabular}{lllllllllllllllll}
\hline Element & $\mathrm{N}$ & $\mathrm{O}$ & $\mathrm{Al}$ & $\mathrm{Nb}$ & $\mathrm{Ti}$ & $\mathrm{Fe}$ & $\mathrm{C}$ & $\mathrm{Mn}$ & $\mathrm{Si}$ & $\mathrm{Cu}$ & $\mathrm{S}$ & $\mathrm{P}$ & $\mathrm{Cr}$ & $\mathrm{Co}$ & $\mathrm{Ni}$ \\
\hline Wt.\% & 00.17 & 01.50 & 01.29 & 01.19 & 01.25 & 00.45 & 00.03 & 00.10 & 00.10 & 00.14 & 00.01 & 00.01 & 22.66 & 20.12 & bal \\
\hline
\end{tabular}

Fig. 1 Scheme of the reaction chamber for glow-discharge treatments (a); engineering drawing of the specimen for fatigue testing (b)

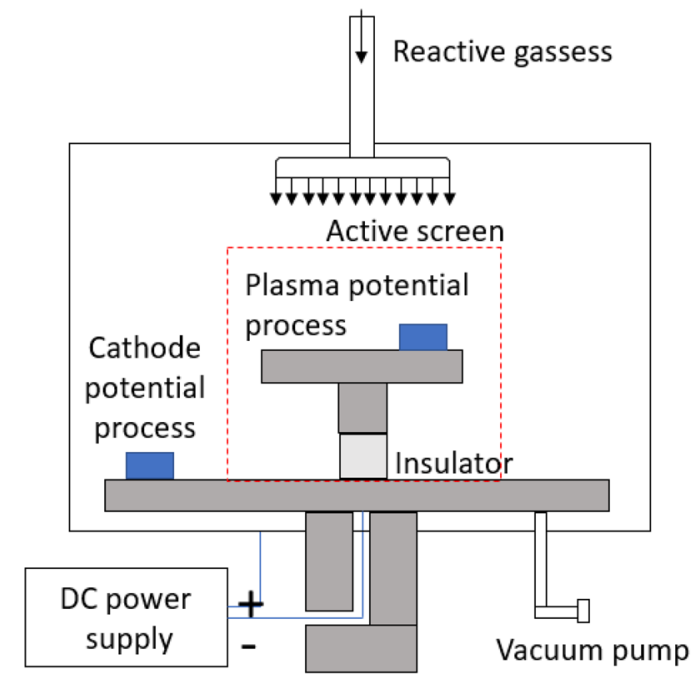

(a)

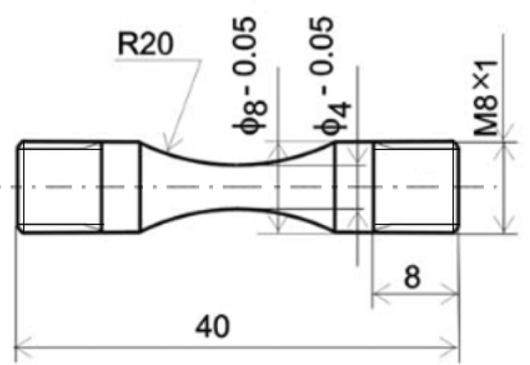

(b) 


\section{Results and discussion}

\subsection{Microstructural characterization of nitrided layers}

Figure 2 shows the cross-sections of the layers produced in the process of glow discharge nitriding at the cathode and plasma potential at temperature of $570{ }^{\circ} \mathrm{C}$ and duration of $8 \mathrm{~h}$. The microscopic observations shown, that the thickness of the nitrided layer at the cathode and plasma potentials were similar and approx. $12 \mu \mathrm{m}$ thick. Below all produced layers, the austenitic matrix with numerous annealing twins and single primary precipitates is clearly seen. The microstructure is composed by grains with a size between 50 and $100 \mu \mathrm{m}$.

The slight difference in the surface topography shown in Fig. 3 results from the technology of the glow discharge nitriding process. The layer generated at the cathode potential (Fig. 3a) has a characteristically developed surface with visible particles well adhered to the layer surface. In the case of layer produced using the plasma potential (Fig. 3b), the surface of layer is less developed due to the limited cathode sputtering phenomenon.

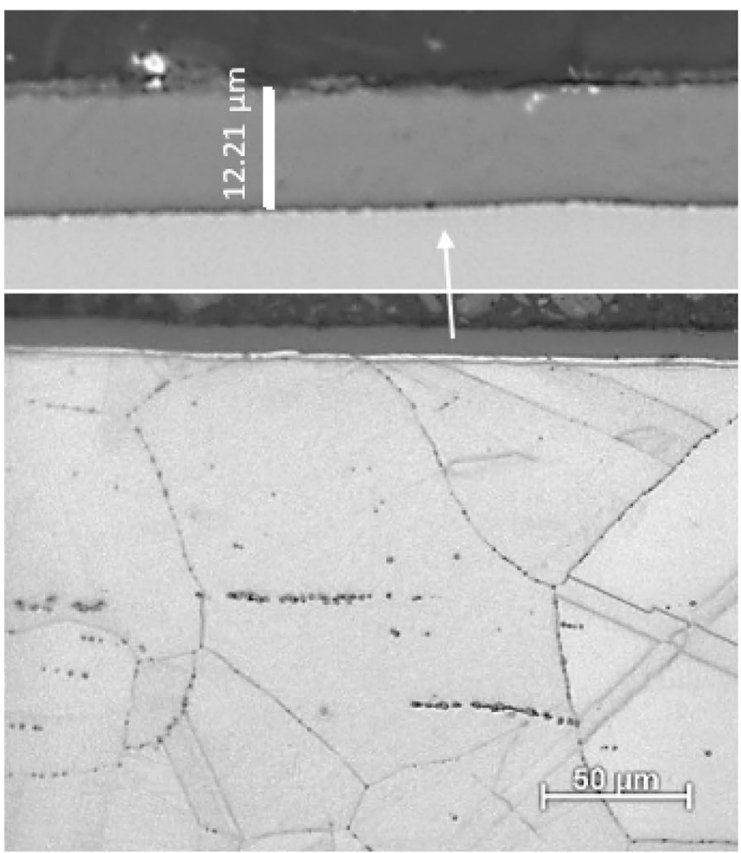

(a)

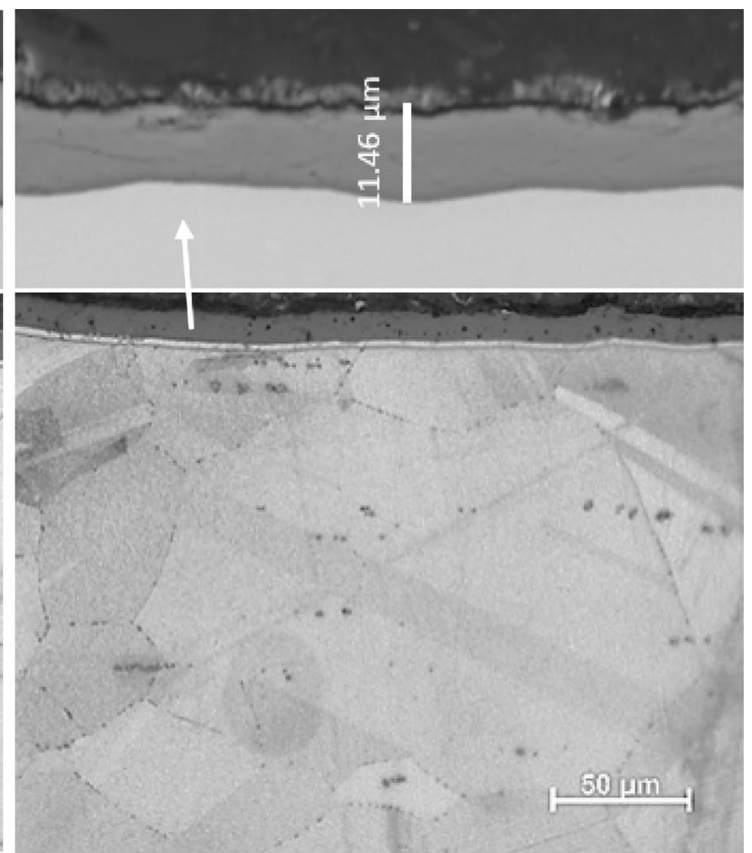

(b)

Fig. 2 The cross-section of CrN layers obtained on Inconel 740H superalloy after nitriding using the cathode (a) and plasma potential (b) (OM)

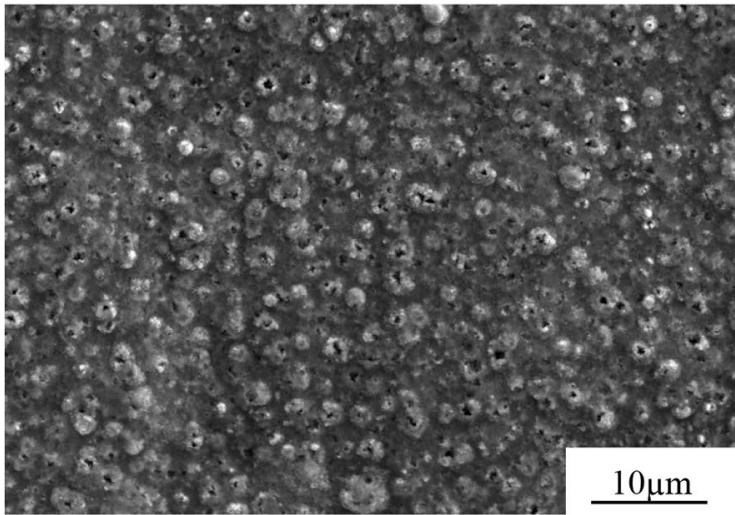

(a)

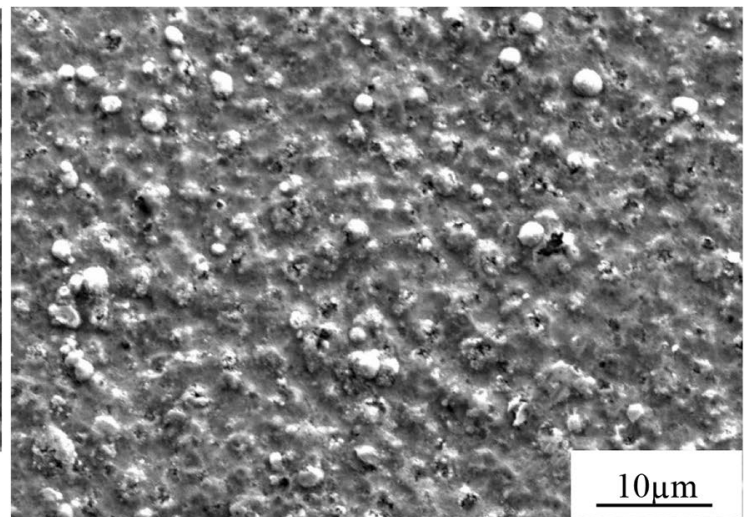

(b)

Fig. 3 Surfaces of nitrided layers formed on Inconel 740H nickel alloy substrate using the cathode (a) and plasma potential (b) (SEM) 
XRD patterns of Inconel $740 \mathrm{H}$ under three conditions are shown in Fig. 4. Figure 4a presents the X-ray spectrum taken from a polished specimen prior to the nitriding process, where the peaks of the alloy matrix consisted mainly chromium, cobalt and nickel are revealed. X-ray phase analysis performed in the angular range from $40^{\circ}$ to $120^{\circ}$ exhibited the presence of chromium, niobium and titanium nitrides in the layers (Fig. 4b, c). Several peaks from titanium, niobium and chromium nitrides were found on the cathode nitrided surface of Inconel 740H (Fig. 4b). The presence of nitrides is associated to the infiltration of the $\mathrm{N}$ element during the nitriding process. Each nitride was identified by a different intensity for the same angle, regardless nitriding methodology used: titanium nitrides; niobium nitrides; and chromium nitrides were found for $44^{\circ}, 50^{\circ}, 72^{\circ}$ and $75^{\circ} ; 49^{\circ}, 71^{\circ}, 86^{\circ}$, $91^{\circ}$ and $113^{\circ}$; and $47^{\circ}, 55^{\circ}, 80^{\circ}$ and $102^{\circ}$, respectively. The peaks from chromium cobalt nickel phase of the nitrided sample were lower in intensity in comparison to the asreceived material (Fig. 4a) as the presence of nitrided layer

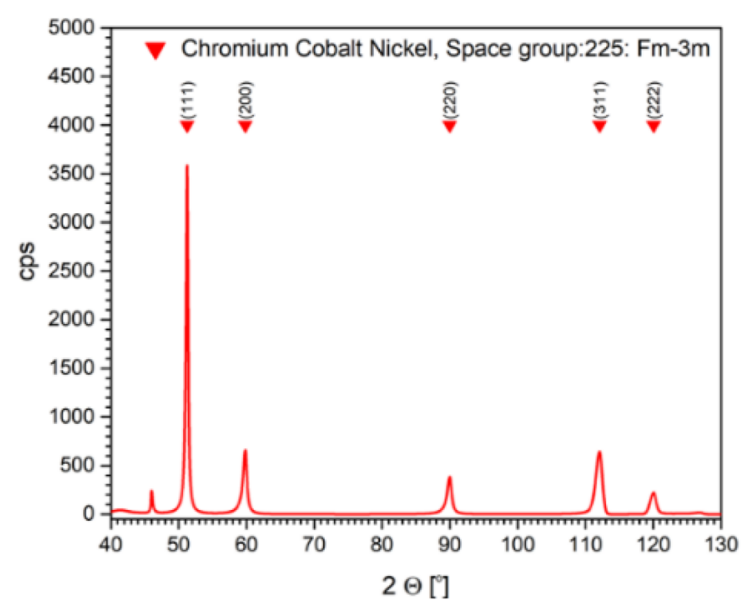

(a) weakens the matrix X-ray signal response. The intensity of titanium, niobium and chromium nitrides is related to the diffusion rate of each element during nitriding process performed at temperature of $570{ }^{\circ} \mathrm{C}$ for $8 \mathrm{~h}$.

\subsection{Effect of Inconel $740 \mathrm{H}$ nitridation on its fatigue response and microhardness profile}

An effect of nitridation on the mechanical properties of the Inconel $740 \mathrm{H}$ was investigated in the standard fatigue tests and microhardness measurements. The results of experiments exhibited, that nitridation enhances a stress response of the Inconel $740 \mathrm{H}$ specimens at the temperature of $23{ }^{\circ} \mathrm{C}$ (Fig. 5a). A positive effect of nitridation on the fatigue response was reported for many structural materials. Genel et al. [20] found, that the fatigue limit increases with an increasing depth of the nitrided layers. Their studies evidenced, that nitriding led to $12 \%$ increase of the fatigue strength of AISI 4140 steel. De Castro et al. [23] reported,

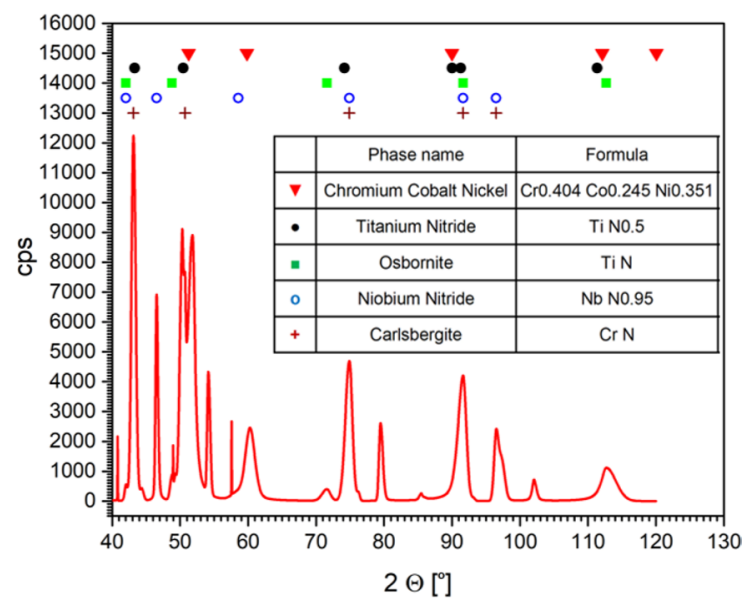

(b)

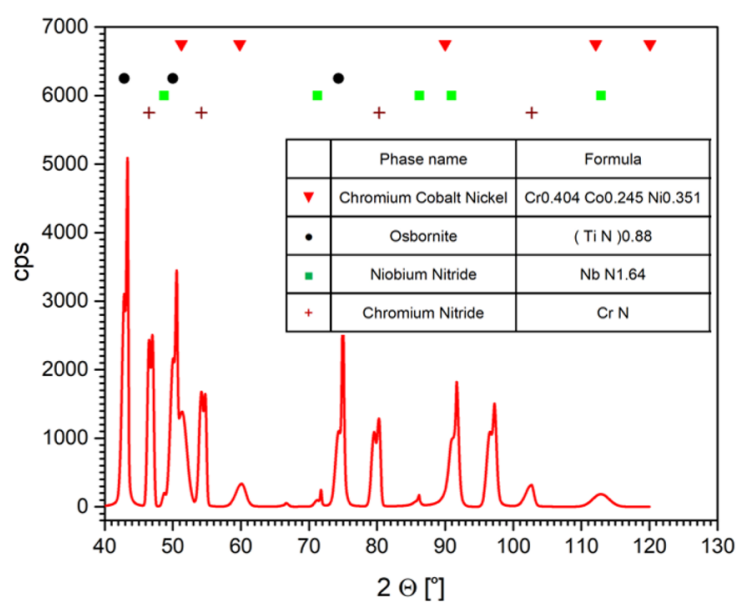

(c)

Fig. 4 X-ray diffractogram of the as-received Inconel $740 \mathrm{H}$ (a), cathode nitrided surface (b) and plasma nitrided surface (c) 


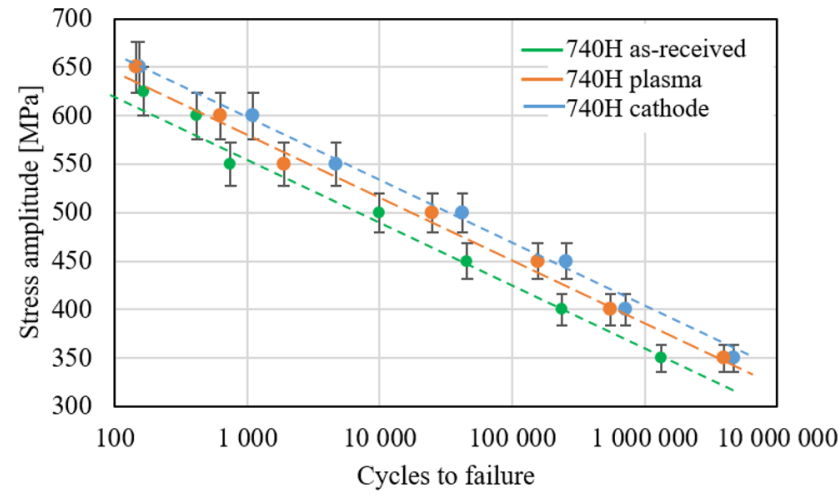

(a)

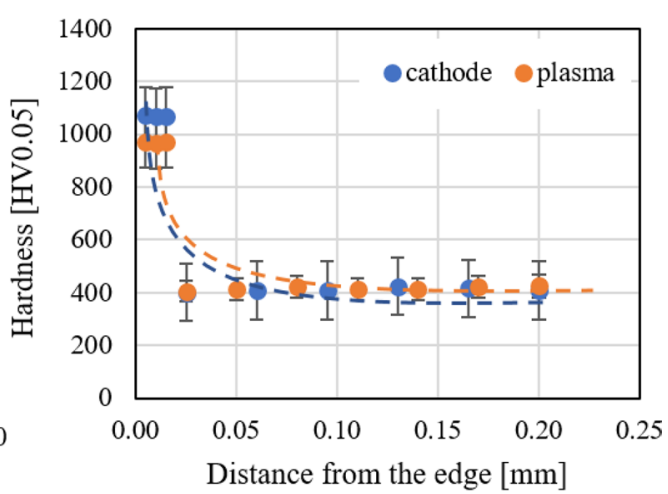

(b)

Fig. 5 The $S-N$ curve for Inconel $740 \mathrm{H}$ under different surface conditions (a); microhardness profiles (b)

that the plasma nitriding enhanced the fatigue behaviour of the Ti-6Al-4V alloy. The extended fatigue life was attributed to the compressive residual stress in the nitrided layers and in the nitrogen diffusion zone, which significantly inhibited crack nucleation at the titanium surface. In the comprehensive review of the nitriding effect on the fatigue strength of structural alloys elaborated by Teren'ev et al. [21], the general reason of fatigue strength increase at the high cycle fatigue was attributed to the creation of stronger surface layer, compressive residual macroscopic stresses and microstresses after surface modification process.

The effect of nitridation on the fatigue behaviour of Inconel type materials was not studied efficiently in the recent literature. Yamane et al. [24] reported, that enhancement of the Inconel 718 fatigue strength at room temperature was mainly caused due to the suppression of crack initiation by the compound layer. Thus, it could be concluded, that the nitridation process positively affected the fatigue behaviour of Inconel $740 \mathrm{H}$. An increase of the fatigue strength was observed in a wide range of strain amplitudes taken into account.

The microhardness profile of the nitrided Inconel $740 \mathrm{H}$ was presented in Fig. 5b. One can indicate that increased hardness of the surface $(\sim 1000 \mathrm{HV} 0.05)$ is characteristic for the nitrided surfaces, since the formation of hard nitrides in the sublayer provides enhanced hardness and toughness of the material. It should be also mentioned, that the nitriding process produces a diffusion layer of $10-100 \mu \mathrm{m}$ thick in which the nitrogen atoms occupy interstitial sites in the crystalline lattice of the substrate material, and subsequently, results on development of the lattice expansion effect. Such expansion leads to the compressive stresses generation that are responsible for a superior toughness and wear resistance properties [26]. The hardness gradually decreased to 400 HV0.05 towards the substrate material.

Micrographs of the fracture surface of nitrided Inconel 740 were presented in Fig. 6. Typical fatigue fracture surface morphologies were observed for all nitrided specimens regardless of the nitriding technique: initiation area with radial streaks along the crack propagation direction and a relatively flat surface (I), propagation area with dimples zone and microvoids (II) and instantaneous fracture area (III). A morphologically and dimensionally homogeneous layer of adhesive nature obtained in the cathodic or plasma nitriding process could be observed for all specimens (Fig. 6). The crack initiation areas were observed in the peripheral zones, at the edge of the specimen, i.e., in the area of stress concentration, where the sub-surface defects or non-metallic inclusions were found for example (zone denoted as "I" in Fig. 6). The propagation area characterized by microvoids consisted also the secondary cracks, which were formed due to jointing pores. The ductile fracture surfaces, of a greater share of the trans-crystalline fracture as well as fine morphological cavities in the form of craters and non-metallic inclusions (carbides) were observed for each specimen. Cleavage steps, parallel to the direction of crack propagation, tend to move together and, as a consequence, form the so-called "river patterns".

\subsection{Effect of the cathode nitriding of Inconel $740 \mathrm{H}$ on its oxidation behaviour}

Inconel $740 \mathrm{H}$ subjected to the cathode plasma nitriding treatment was characterized by the enhanced fatigue performance at room temperature. Since such material is dedicated to high temperature applications, specimens were subjected to the heat resistance test at $1000{ }^{\circ} \mathrm{C}$ for $100 \mathrm{~h}$ in an air atmosphere. The cross-sectional view of the specimen after $5 \mathrm{~h}$ revealed, that a significantly thicker scale was formed on the surface in the as-received state (Fig. 7a). Such scale was characterized by $10 \%$ lower content of the cobalt in comparison to the nitrided specimen and higher content of oxide (Table 2). The unmodified surface was therefore more susceptible for oxidation and a thicker sublayer was formed. 
It was noticed, that the nitrided surface was much resistant to microstructural changes as almost two times smaller area of elements diffusion was observed (Fig. 7b). Such diffusion zones are characterized by an increased content of aluminium, since a relatively high temperature results on the diffusion of its atoms to the surface. It has to be mentioned however, that a tight chromium oxide sublayer protects the substrate against oxidation and diffusion of aluminium atoms to the surface.

Extension of annealing time up to $50 \mathrm{~h}$ significantly affected the thickness of chromium oxide layer resulting on its increase from 7 to $20 \mu \mathrm{m}$ for the nitrided surface (Fig. 8b) and from 9 to $25 \mu \mathrm{m}$ for the unmodified surface in comparison to $5 \mathrm{~h}$ of high temperature exposure (Fig. 8a). The chemical composition of the oxide layer remained stable, however, the content of aluminium in the diffusion zone was more than twice times higher (Table 3). One should notice, that the thickness of the diffusion zone increased significantly from 7 to $65 \mu \mathrm{m}$ for the nitrided surface and from 15 to $90 \mu \mathrm{m}$ for the unmodified surface. A relatively long time of anealing led to the further diffusion of aluminium atoms to the surface, but still was inhibited by the chromium oxide. The protective scale formed on the nitrided surface contained nitrogen and oxygen enriched, which may indicate a formation of titanium, chromium and cobalt oxides and nitrides. It should be highlighted, that nitriding itself led to the difussion of nitrogen resulting in formation of nitrides not only on the material surface, but also within material volume. Chemical composition analysis performed in diffusion zone revealed titanium nitrides (Fig. 8c, d). The presence of such nitrides may explain the relatively high hardness measured in the diffusion zone (Fig. 5b) as this refractory compound with superior properties significantely strenghten the matrix material.

\subsection{Effect of the plasma nitriding of Inconel $740 \mathrm{H}$ on its oxidation behaviour}

In the second part of the experimental program an effect of the plasma nitriding was studied. The surface of Inconel $740 \mathrm{H}$ subjected to the plasma nitriding treatment after 5-h high temperature exposure was characterized by the brittle, almost $7 \mu \mathrm{m}$ thick, chromium oxide layer with an increased content of the titanium and niobium (Fig. 9, Table 4). The chromium oxide-based sublayer of $8 \mu \mathrm{m}$ thickness and $27-\mu \mathrm{m}$-thick diffusion zone were formed near the surface. The increased content of aluminium was found in the diffusion zone. It should be noticed, however, that the brittle scale was not able to fully protect the substrate against the high temperature exposure. As a consequence, the diffusion zone was thicker for the nitrided material by almost $10 \mu \mathrm{m}$. However, a distribution of elements near the surface remained similar to those observed for the cathode nitrided.
Extension of the homogenization time up to $50 \mathrm{~h}$ led to a significant increase of the chromium oxide zone thickness in the unnitrided zone by $10 \mu \mathrm{m}$ and a total increase of the thickness over the entire zone by $45 \%$. The significant content of nickel (44\%) and oxide (18\%) could be found in the scale of the plasma nitrided Inconel $740 \mathrm{H}$ subjected to the high temperature aneealing. The diffusion of nickel was successfully inhibited by the chromium oxide sublayer, however, the diffusion zone was grown considerably to almost $150 \mu \mathrm{m}$ (Fig. 10a). On the other hand, in the nitrided surface, the entire zone of the chromium oxide layer thickness increased from 7 to $20 \mu \mathrm{m}$ exhibiting the same tendency as that for the cathode nitriding observed. The scale of $10 \mu \mathrm{m}$ was characterized by an increased content of the nickel (Fig. 10b, Table 5). It should be noted however, that the thickness of the sublayer formed was considerably lower than that for the plasma nitrided material obtained without any heat treatment application. Additionally, the diffusion zone was almost three times thicker in comparison to that of the unmodified Inconel $740 \mathrm{H}$.

\subsection{Effect of the nitriding technique on oxidation and mechanical response of Inconel $740 \mathrm{H}$ alloy}

Nitriding is the well-known technology, that can improve the hardness, wear and corrosion resistance of surfaces. It was found, that Inconel $740 \mathrm{H}$ subjected to the nitriding can be characterized by almost $260 \%$ improvement of surface hardness in the case of the cathode nitride process usage and $230 \%$ for the plasma nitrided one (Fig. 5b). Additionally, a hardness enhancement for the plasma nitrided Inconel $740 \mathrm{H}$ was observed not only for the surface, but also in some distance from the edge of the modified surface. It may prove the higher effectiveness of the plasma nitriding over cathode one. Similar response was reported by Xue et al. [26]. They have shown the significant enhancement of hardness of the nitrided layer formed on Inconel 718 surface. It was equal to $1810 \mathrm{HV} 0.01$ and was $352 \%$ higher than that for the substrate material. Maniee et al. [27] shown, that the hot wall plasma nitriding at $450{ }^{\circ} \mathrm{C}$ could enhance the surface hardness, wear and corrosion resistance of Inconel 718. In this study, the maximum value of surface hardness equal to $1600 \mathrm{HV} 0.05$ was obtained for the specimen nitrided at $500{ }^{\circ} \mathrm{C}$. Such value was around four times harder than the untreated sample (418 HV0.05). Zhang et al. [28] used the low temperature gas nitriding to improve hardness and surface roughness for the same type of alloy. It was reported, that ultrasonic nanocrystal surface modification followed by low-temperature gas nitriding increased the surface hardness of the Inconel 718 by $190 \%$. Borowski et al. [29] studied hardness, frictional wear resistance, fatigue strength and corrosion resistance of Inconel 625 modified using glow discharge-assisted nitriding. In this study, a hardness of 

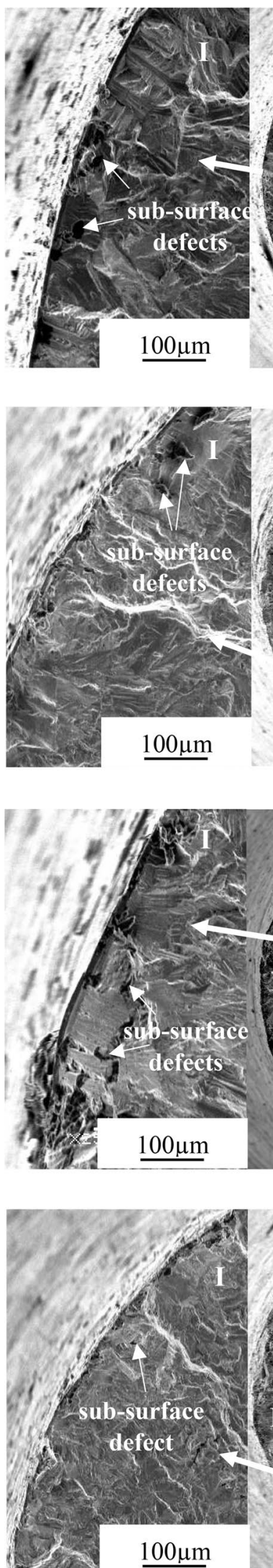

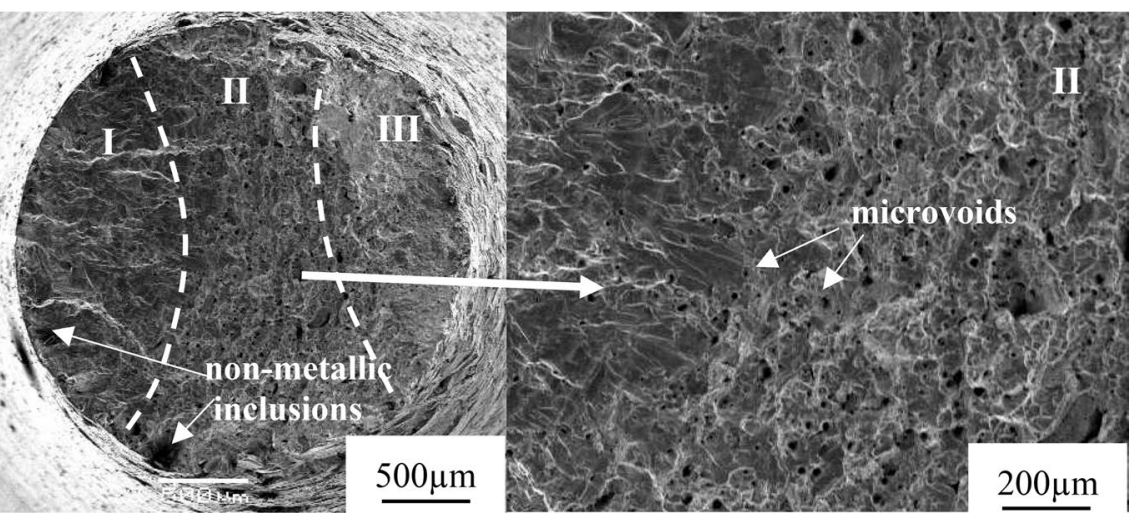

(a)

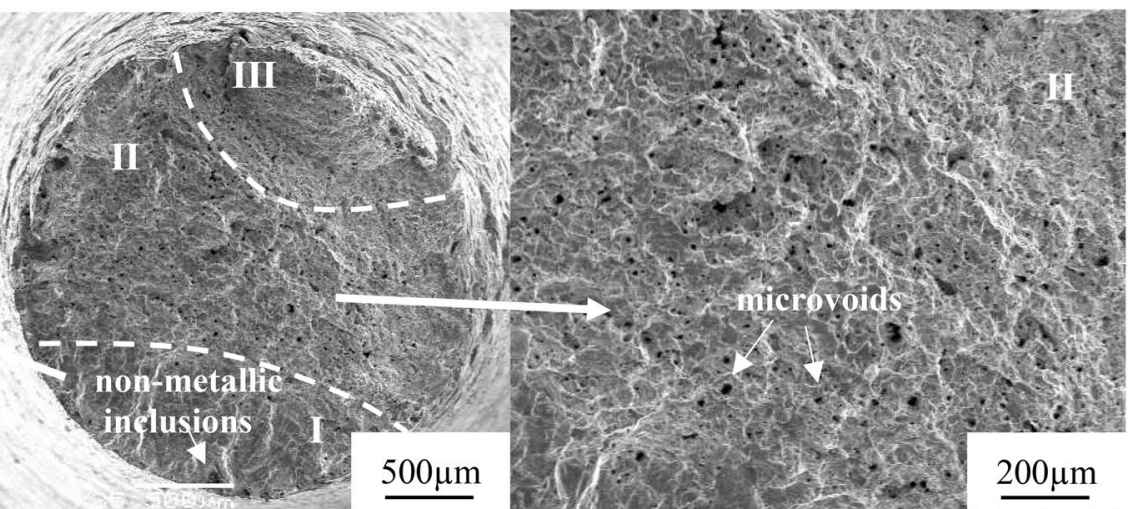

(b)

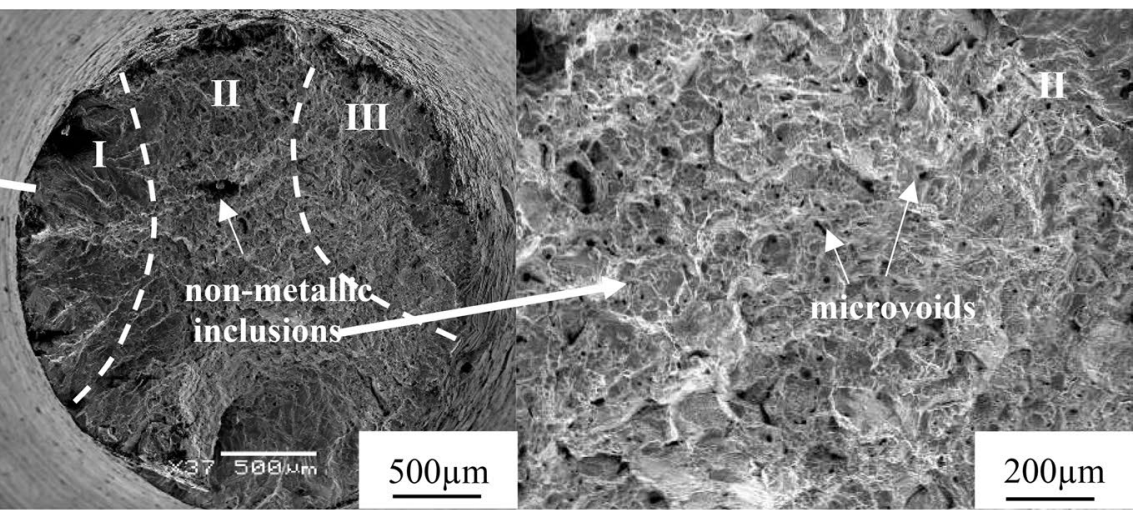

(c)

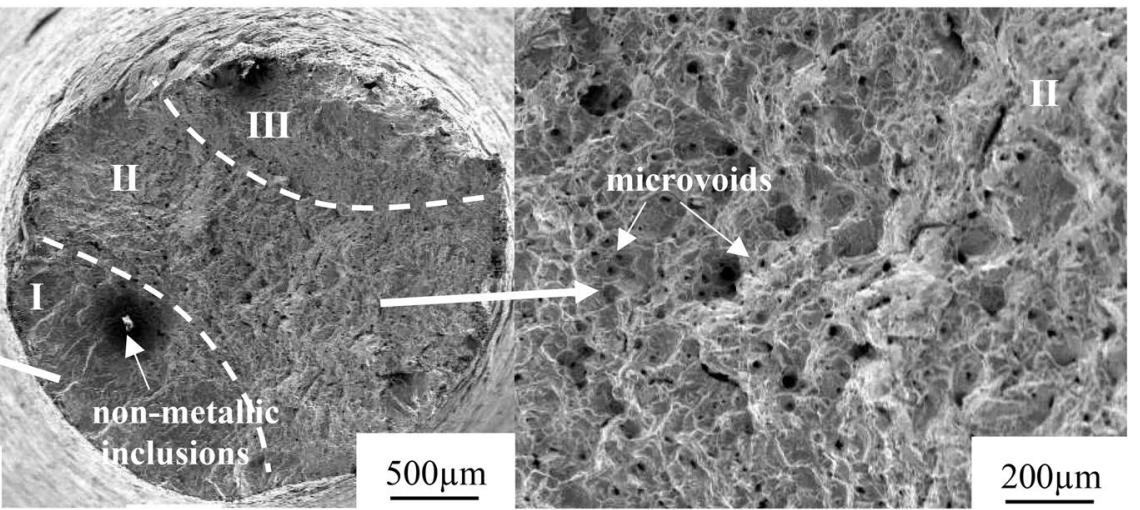

(d) 
4Fig. 6 The cathode nitrided Inconel $740 \mathrm{H}$ fatigue fracture surfaces for stress amplitude equal to $600 \mathrm{MPa}$ (a) and $700 \mathrm{MPa}$ (b); the plasma nitrided Inconel $740 \mathrm{H}$ fatigue fracture surfaces for stress amplitude equal to $600 \mathrm{MPa}(\mathbf{c})$ and $700 \mathrm{MPa}(\mathbf{d})$ (SEM)

nitrided surface of $1480 \mathrm{HV} 0.05$ was obtained (compared with 380HV0.05 of untreated Inconel 625).

In terms of the corrosion resistance, both the plasma and cathode nitriding can be characterized by a progressive increase of weight gain up to $50 \mathrm{~h}$ of annealing (Fig. 11). A loss of the relative weight gain for $100 \mathrm{~h}$ was associated with the brittleness of scale formed, that fall off from the surface. It should be mentioned however, that for the plasma nitrided specimens, both the relative weight gain and thickness of the chromium-rich scale were steadily growing up to $0.5 \%$ for $50 \mathrm{~h}$ (Fig. 11a, c), while the nitriding depth remained at the stable level of about $100 \mu \mathrm{m}$. The microscopic observations of this particular scale identified the uniform distribution of the chromium rich layer and nitriding depth after 50 and $100 \mathrm{~h}$ (Fig. 12a, c). It may suggest, that the scale formed on the plasma nitrided surface has better protective properties. On the other hand, the cathode nitrided specimens were characterized by considerable relative weight increase even after $5 \mathrm{~h}$ of annealing, which remained at a stable level of $0.7-0.9 \%$ till the scale fell off from the surface (Fig. 11a). The loss of protective scale led to an increase of the diffusion zone thickness in which nitrides were found (Figs. 8c, $\mathrm{d}, 11 \mathrm{~b}, 12 \mathrm{~d}$ ), which indicates, that the cathode nitriding may not be suitable for high temperature applications.

According to Pilarska et al. [30], an increase of the nitriding depth result from the ion energy acting on the nitrided substrate. It was reported, that during cathode nitriding, the substrate surface was bombarded by a high energy ions whose values were cathode polarization voltage dependent. Under the plasma potential nitriding conditions however, the ions had significantly lower energy resulting from the smaller size of the floating potential. It was concluded, that the complementary potential enhances the polarity of the workpiece with respect to plasma potential nitriding. Such behaviour led to the nitriding process intensification, and thus, a subsequent increase in the concentration of nitrogen in the surface layer was observed.

It should be mentioned however, that both of the nitriding techniques applied in this research enable a slight reduction of the thickness of chromium-rich scale in comparison to the as-received material (Fig. 11c). The positive effect of nitriding on the corrosion resistance of nickel-based alloys was also indicated in the literature. Xue et al. [26] reported a significant improvement in the erosion-corrosion resistance (almost 80.3\%) if compared to the as-received Inconel 718. Such improvement was associated to the chromium nitride found on the surface. The same nitrides were found on the surface of nitrided Inconel $740 \mathrm{H}$, as presented in Fig. 4. It could be concluded, that these nitrides along with titanium nitrides effectively improve the mechanical properties of Inconel $740 \mathrm{H}$ including fatigue parameters and hardness.

Taking above observations into account it can be concluded, that the nitriding technology is widely used to improve the properties of Inconel alloys. One can state, that the cathode and plasma nitriding technology presented in this paper could be successfully applied for fatigue and high temperature corrosion enhancement of Inconel 740H.

\section{Conclusions}

In this paper, the mechanical properties of the nitrided Inconel $740 \mathrm{H}$ alloy were examined using microhardness measurements and standard fatigue tests. The nitrided Inconel $740 \mathrm{H}$ exhibited the significant improvement of fatigue response of order equal to $50 \mathrm{MPa}$ in the whole range of stress amplitudes from 350 to $650 \mathrm{MPa}$, and almost 230\% increase of hardness for the plasma modified surface and $260 \%$ in the case of cathode modified surface. Additionally, an application of the nitriding enhances the corrosion resistance of Inconel $740 \mathrm{H}$ by the effective protection of its surface against the high temperature oxidation. The relative weight gain for the cathode nitrided Inconel $740 \mathrm{H}$ was greater and faster than for the plasma nitrided, which was attributed to the higher efficiency of the nitridation method. The thickness of the plasma nitrided layer stabilizes itself after about $50 \mathrm{~h}$ of annealing at the level of $100 \mu \mathrm{m}$, and for such temperature it was $50 \%$ lower than that obtained for the cathode nitride Inconel $740 \mathrm{H}$. The stability of the nitrided layer thickness corresponded to the stabilization of the chromium oxide during the high temperature annealing at $1000{ }^{\circ} \mathrm{C}$ either for 50 or $100 \mathrm{~h}$. 


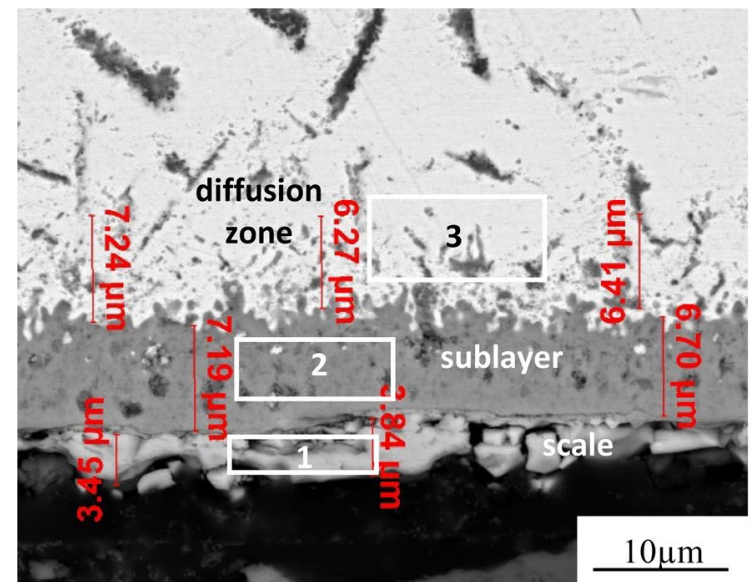

(a)

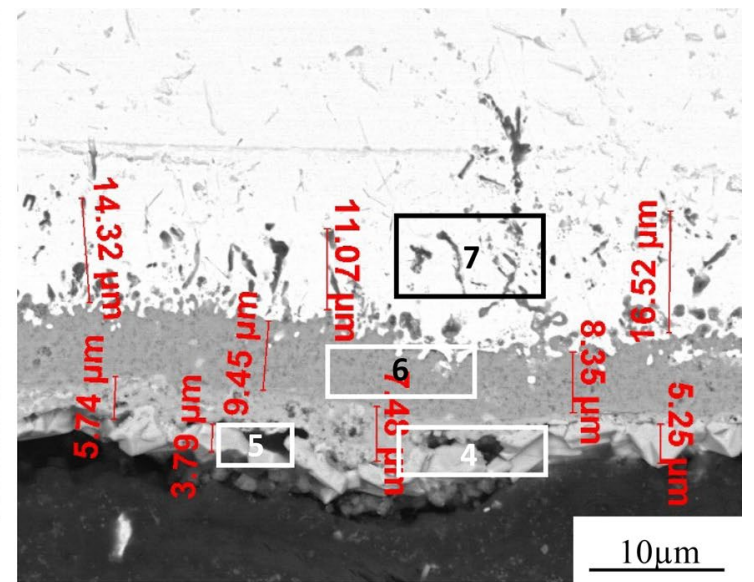

(b)

Fig. 7 The cross-sectional views of: a the cathode nitrided Inconel $740 \mathrm{H}$; b as-received material after $5 \mathrm{~h}$ annealing at $1000{ }^{\circ} \mathrm{C}(\mathrm{SEM})$

Table 2 Chemical composition of the specific regions of cathode nitrided Inconel $740 \mathrm{H}(1,2,3)$ and as-received material after $5 \mathrm{~h}$ annealing at $1000{ }^{\circ} \mathrm{C}(4,5,6,7)$

\begin{tabular}{lllllllll}
\hline Element & $\mathrm{N}$ & $\mathrm{O}$ & $\mathrm{Al}$ & $\mathrm{Nb}$ & $\mathrm{Ti}$ & $\mathrm{Cr}$ & $\mathrm{Co}$ & $\mathrm{Ni}$ \\
\hline 1 & 00.65 & 13.54 & 00.18 & 00.15 & 00.25 & 01.81 & 26.84 & 56.58 \\
2 & 02.77 & 26.92 & 00.31 & 00.42 & 01.05 & 67.20 & 00.35 & 00.98 \\
3 & 00.58 & 05.62 & 03.33 & 01.15 & 00.64 & 16.25 & 20.13 & 52.30 \\
4 & 01.00 & 15.99 & 00.11 & 00.22 & 00.21 & 02.08 & 17.95 & 62.45 \\
5 & 02.00 & 21.85 & 01.47 & 02.79 & 03.40 & 35.27 & 19.25 & 13.97 \\
6 & 02.91 & 24.46 & 00.36 & 01.20 & 01.75 & 67.63 & 00.41 & 00.70 \\
7 & 01.04 & 03.61 & 04.57 & 01.18 & 01.18 & 12.21 & 21.87 & 54.96 \\
\hline
\end{tabular}




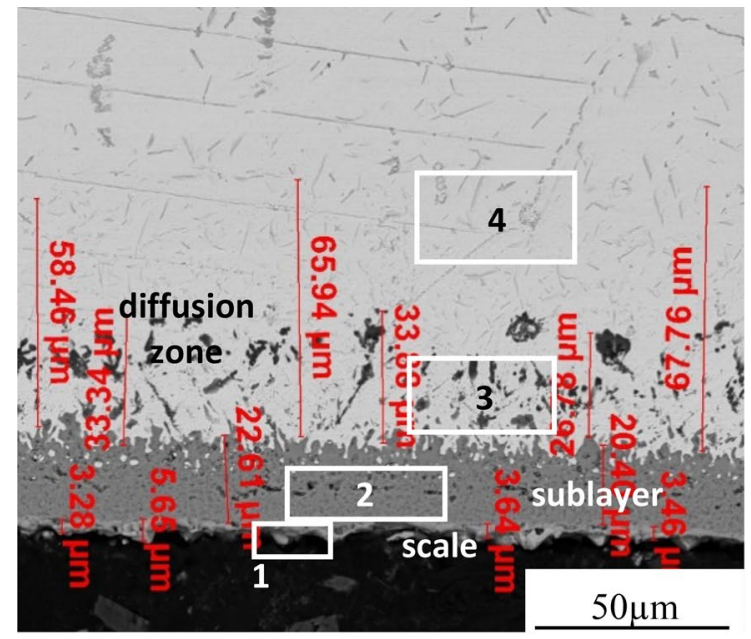

(a)

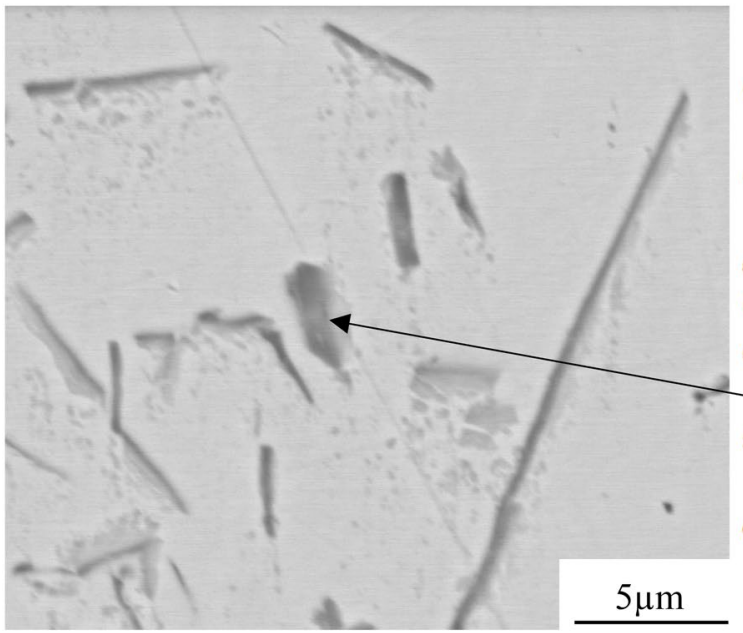

(c)

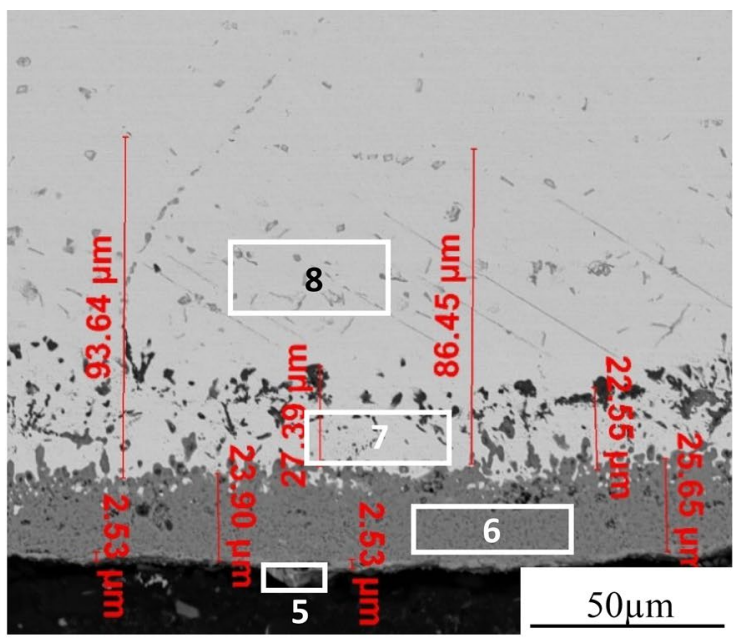

(b)

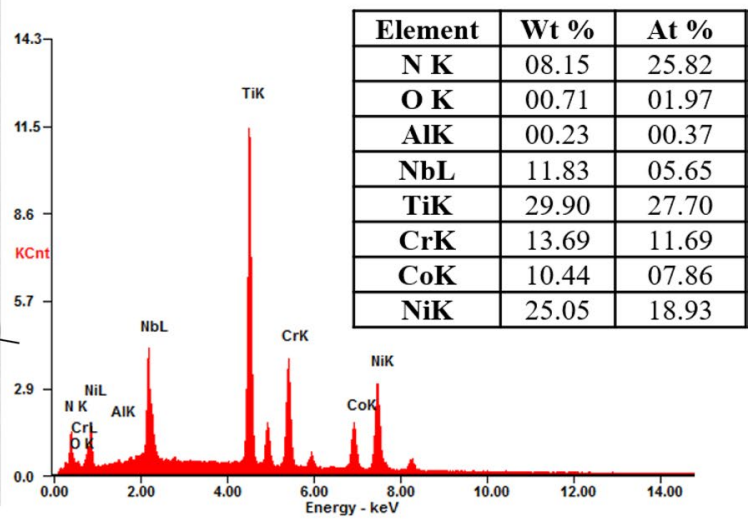

(d)

Fig. 8 The cross-sectional views of: a the cathode nitrided Inconel $740 \mathrm{H}(1,2,3,4)$; $\mathbf{b}$ as-received material after $50 \mathrm{~h}$ annealing at $1000{ }^{\circ} \mathrm{C}(5,6$, $7,8)$; $\mathbf{c}$ enlarged diffusion area; $\mathbf{d}$ chemical composition of titanium nitride (SEM)

Table 3 Chemical composition of the specific regions of the cathode nitrided Inconel $740 \mathrm{H}$ $(1,2,3,4)$ and the as-received material after $50 \mathrm{~h}$ annealing at $1000{ }^{\circ} \mathrm{C}(5,6,7,8)$

\begin{tabular}{lllllllll}
\hline Element & $\mathrm{N}$ & $\mathrm{O}$ & $\mathrm{Al}$ & $\mathrm{Nb}$ & $\mathrm{Ti}$ & $\mathrm{Cr}$ & $\mathrm{Co}$ & $\mathrm{Ni}$ \\
\hline 1 & 03.41 & 30.98 & 00.87 & 03.07 & 08.71 & 14.48 & 14.96 & 23.52 \\
2 & 03.04 & 26.38 & 00.08 & 00.39 & 01.18 & 67.68 & 00.42 & 00.83 \\
3 & 01.21 & 04.79 & 07.47 & 01.57 & 00.93 & 12.51 & 20.77 & 50.76 \\
4 & 01.51 & 01.85 & 00.42 & 01.90 & 01.97 & 17.70 & 21.25 & 53.40 \\
5 & 01.87 & 15.74 & 00.51 & 00.98 & 02.92 & 09.36 & 11.71 & 56.91 \\
6 & 02.81 & 26.16 & 00.17 & 00.57 & 01.31 & 68.07 & 00.27 & 00.63 \\
7 & 01.12 & 05.44 & 10.25 & 01.48 & 00.17 & 09.25 & 20.62 & 51.67 \\
8 & 01.56 & 02.02 & 00.65 & 01.64 & 02.57 & 19.57 & 20.22 & 51.77 \\
\hline
\end{tabular}




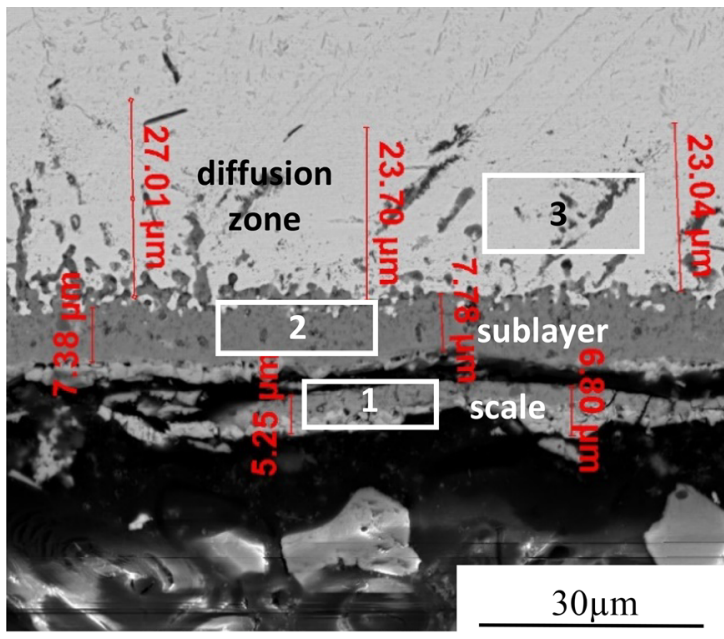

(a)

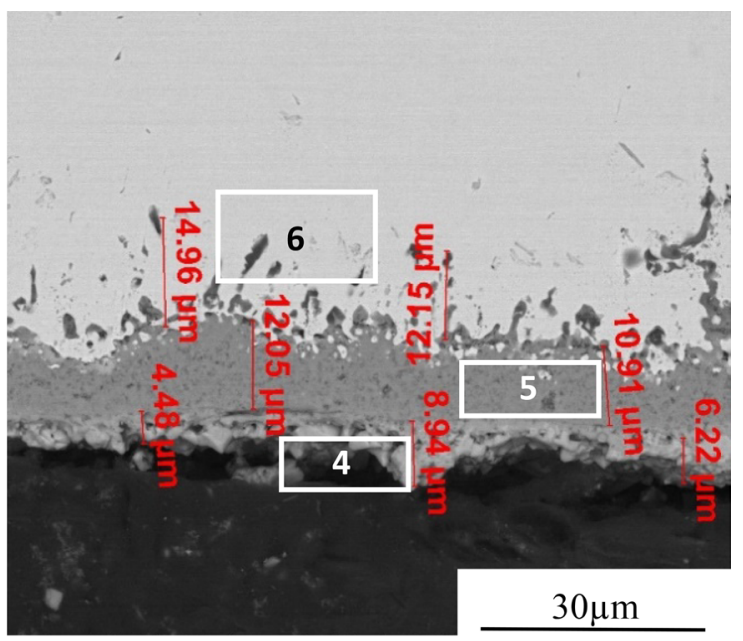

(b)

Fig. 9 The cross-sectional view of: a the plasma nitrided Inconel $740 \mathrm{H}(1,2,3)$; b as-received material after $5 \mathrm{~h}$ annealing at $1000{ }^{\circ} \mathrm{C}(4,5,6)$ (SEM)

Table 4 Chemical composition of the specific regions of plasma nitrided Inconel $740 \mathrm{H}(1,2,3)$ and the as-received material after $5 \mathrm{~h}$ annealing at $1000{ }^{\circ} \mathrm{C}$ $(4,5,6)$

\begin{tabular}{lllllllll}
\hline Element & $\mathrm{N}$ & $\mathrm{O}$ & $\mathrm{Al}$ & $\mathrm{Nb}$ & $\mathrm{Ti}$ & $\mathrm{Cr}$ & $\mathrm{Co}$ & $\mathrm{Ni}$ \\
\hline 1 & 02.69 & 25.09 & 01.37 & 06.13 & 03.68 & 37.52 & 12.19 & 11.33 \\
2 & 02.79 & 26.38 & 00.34 & 00.83 & 01.39 & 67.06 & 00.32 & 00.89 \\
3 & 00.62 & 02.63 & 02.82 & 01.80 & 02.00 & 16.53 & 21.17 & 52.44 \\
4 & 01.89 & 20.11 & 00.67 & 01.21 & 01.53 & 10.81 & 17.81 & 45.96 \\
5 & 02.98 & 25.18 & 00.36 & 00.86 & 02.29 & 67.35 & 00.04 & 00.94 \\
6 & 00.10 & 02.49 & 06.02 & 01.60 & 00.83 & 11.54 & 22.59 & 54.83 \\
\hline
\end{tabular}

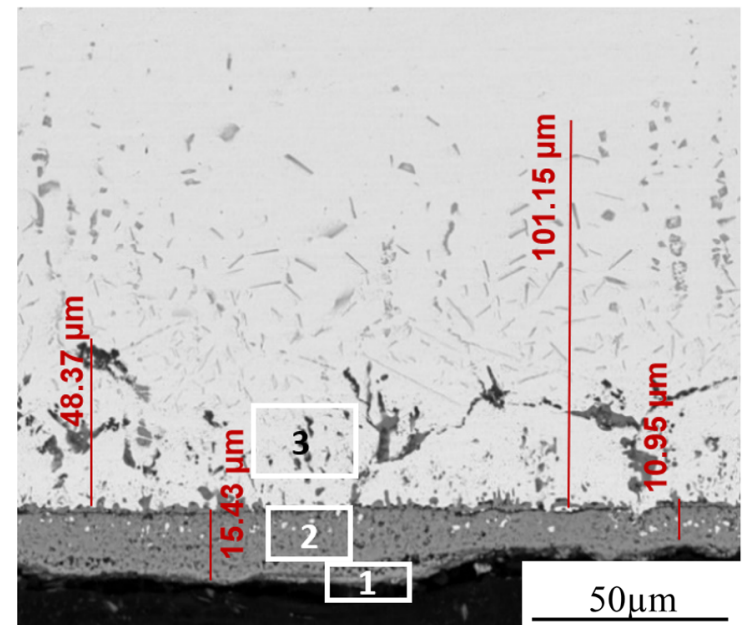

(a)

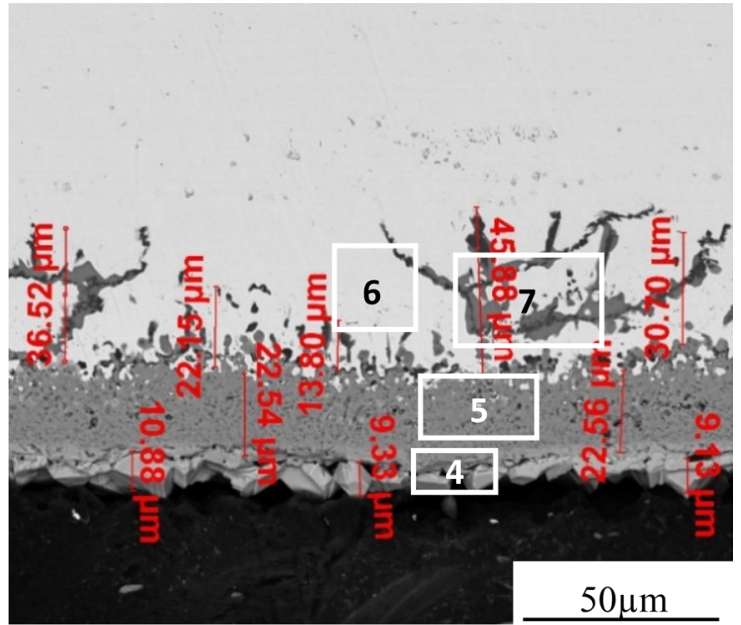

(b)

Fig. 10 The cross-sectional view of: a the plasma nitrided Inconel $740 \mathrm{H}$; b as-received material after $50 \mathrm{~h}$ annealing at $1000{ }^{\circ} \mathrm{C}(\mathrm{SEM})$ 
Table 5 Chemical composition of the specific regions of the plasma nitrided Inconel $740 \mathrm{H}$ and the as-received material after $50 \mathrm{~h}$ annealing at $1000{ }^{\circ} \mathrm{C}$

\begin{tabular}{lllllllll}
\hline Element & $\mathrm{N}$ & $\mathrm{O}$ & $\mathrm{Al}$ & $\mathrm{Nb}$ & $\mathrm{Ti}$ & $\mathrm{Cr}$ & $\mathrm{Co}$ & $\mathrm{Ni}$ \\
\hline 1 & 02.12 & 18.03 & 00.70 & 02.01 & 04.14 & 13.73 & 14.78 & 44.50 \\
2 & 02.74 & 24.88 & 00.18 & 00.16 & 01.46 & 68.03 & 00.76 & 01.78 \\
3 & 01.12 & 04.81 & 04.50 & 02.54 & 01.31 & 14.66 & 20.89 & 50.17 \\
4 & 02.13 & 17.34 & 00.10 & 00.23 & 00.50 & 01.84 & 16.78 & 61.09 \\
5 & 02.88 & 26.83 & 00.17 & 01.50 & 02.38 & 64.96 & 00.33 & 00.95 \\
6 & 01.66 & 08.10 & 05.08 & 02.91 & 04.29 & 16.86 & 17.78 & 43.31 \\
7 & 02.25 & 07.27 & 08.46 & 01.60 & 10.26 & 13.12 & 16.86 & 40.17 \\
\hline
\end{tabular}

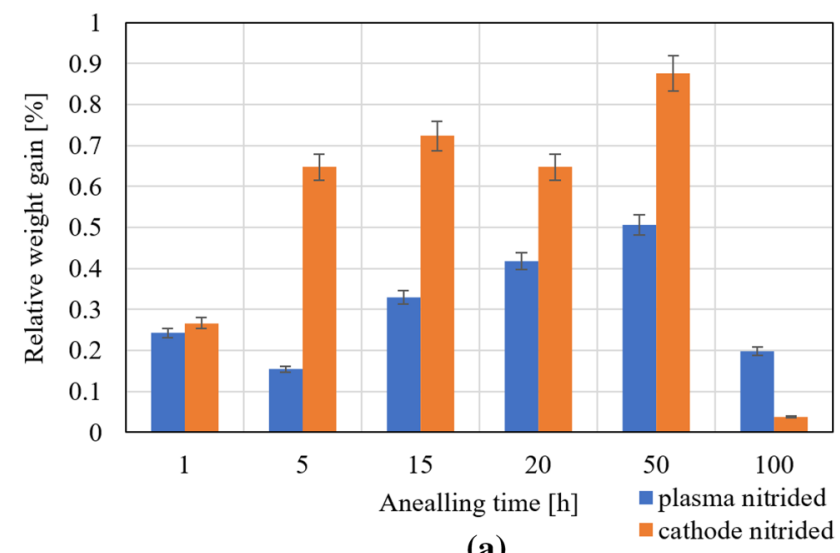

(a)

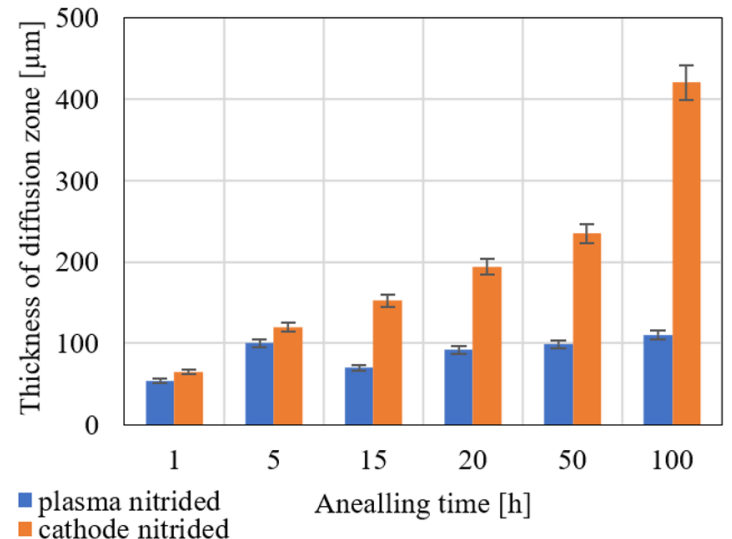

(b)

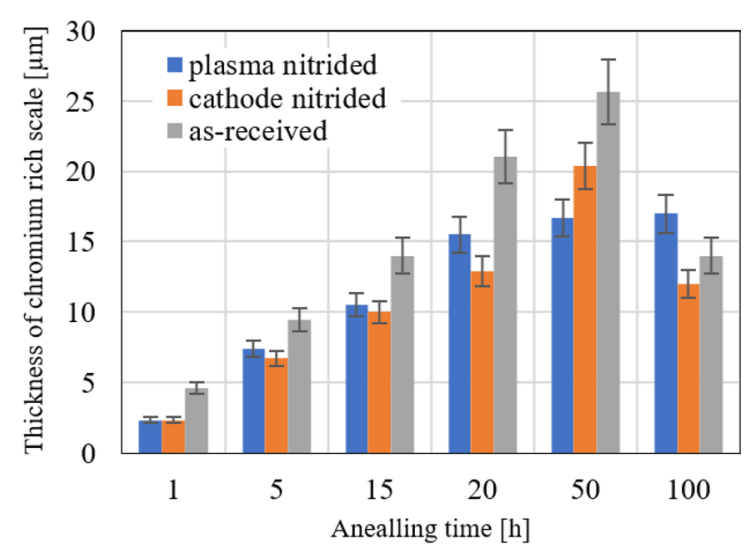

(c)
Fig. 11 The comparison of relative weight gain for the plasma and cathode nitrided Inconel $740 \mathrm{H}$ after annealing at $1000{ }^{\circ} \mathrm{C}(\mathbf{a})$; the comparison of diffusion zone thickness (b) and thickness of chro-

mium-rich scale (c) for the cathode nitrided, plasma nitrided Inconel $740 \mathrm{H}$ and as-received Inconel $740 \mathrm{H}$ after annealing at $1000{ }^{\circ} \mathrm{C}$ 


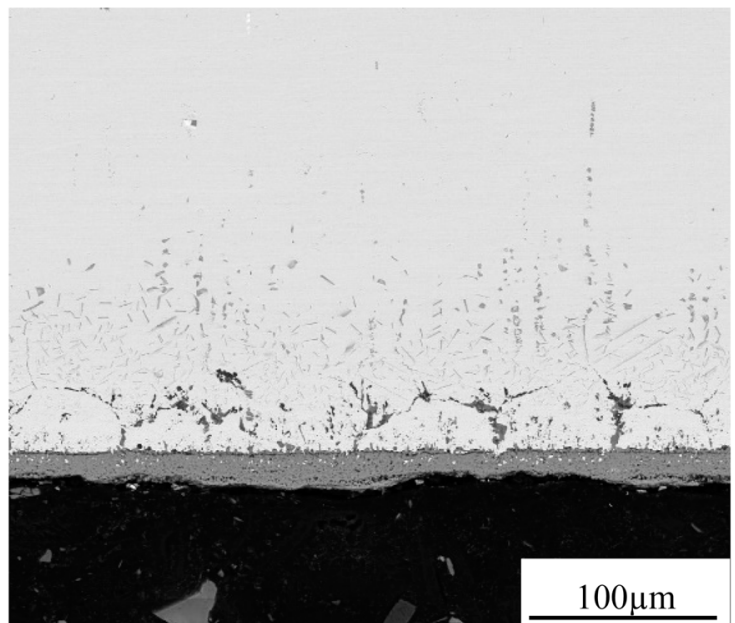

(a)

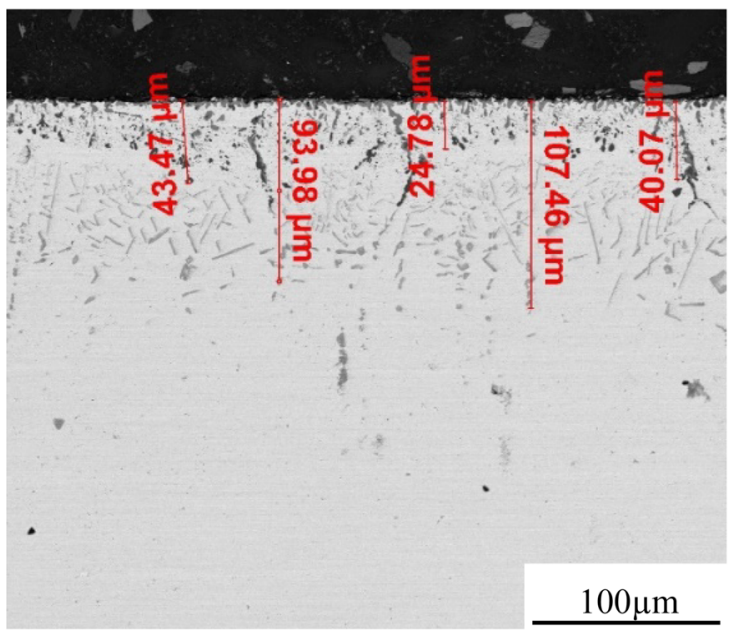

(c)

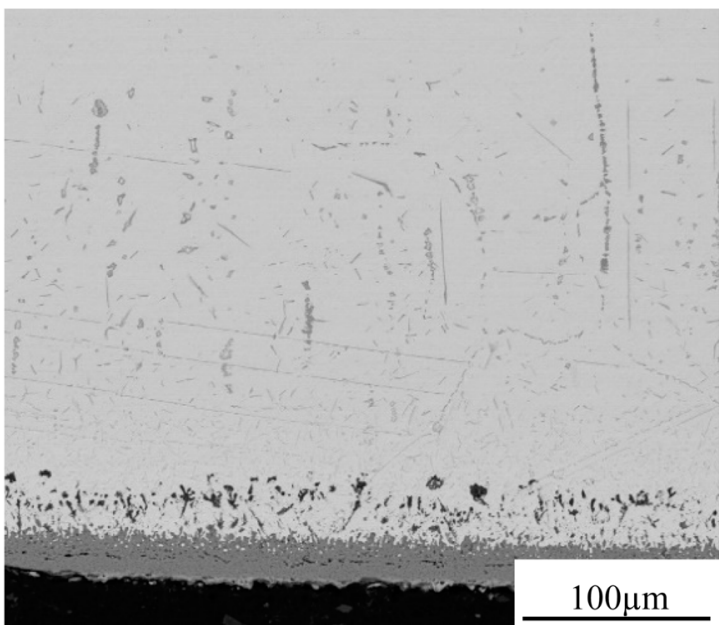

(b)

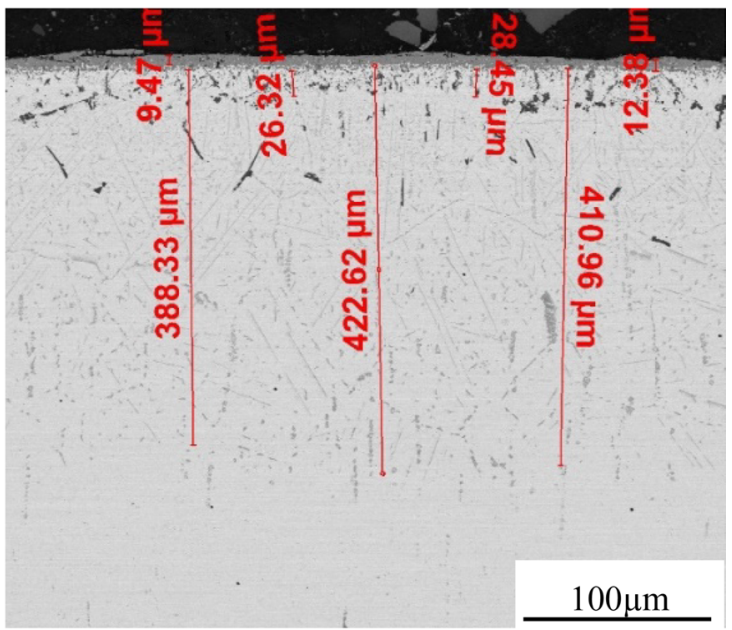

(d)

Fig. 12 Comparison of the cross-sectional view of the plasma nitrided (a) and cathode nitrided (b) Inconel $740 \mathrm{H}$ after $50 \mathrm{~h}$ and comparison of nitriding depth for the plasma (c) and cathode (d) nitrided Inconel $740 \mathrm{H}$ after annealing for $100 \mathrm{~h}$ at $1000{ }^{\circ} \mathrm{C}(\mathrm{SEM})$

Acknowledgements The authors are grateful to Mirosław Wyszkowski and Andrzej Chojnacki from the Institute of Fundamental Technological Research of the Polish Academy of Sciences for their great support in the experimental part of this work.

Funding The authors gratefully acknowledge the financial support of the Structural Funds within the framework of the Operational Programme-Innovative Economy (IE OP), financed from the European Regional Development Fund-Project entitled ',Modern material technologies in aerospace industry', Nr POIG.01.01.02-00-015/08-01.

\section{Declarations}

Conflict of interest The authors declare that they have no known competing financial interests or personal relationships that could have appeared to influence the work reported in this paper.

Ethical approval This article does not contain any studies with human participants or animals performed by any of the authors.
Open Access This article is licensed under a Creative Commons Attribution 4.0 International License, which permits use, sharing, adaptation, distribution and reproduction in any medium or format, as long as you give appropriate credit to the original author(s) and the source, provide a link to the Creative Commons licence, and indicate if changes were made. The images or other third party material in this article are included in the article's Creative Commons licence, unless indicated otherwise in a credit line to the material. If material is not included in the article's Creative Commons licence and your intended use is not permitted by statutory regulation or exceeds the permitted use, you will need to obtain permission directly from the copyright holder. To view a copy of this licence, visit http://creativecommons.org/licenses/by/4.0/.

\section{References}

1. Zieliński A, Sroka M, Dudziak T. Microstructure and mechanical properties of Inconel $740 \mathrm{H}$ after long, term service. Materials. 2018;11:2130. https://doi.org/10.3390/ma11112130. 
2. de Barbadillo JJ, Baker BA, Gollihue RD, McCoy SA (2018) Properties of INCONEL alloy $740 \mathrm{H}$ for high pressure steam and supercritical $\mathrm{CO}_{2}$ applications. In: Proceedings of the ASME 2018 symposium on elevated temperature application of materials for fossil, nuclear, and petrochemical industries. ASME 2018 symposium on elevated temperature application of materials for fossil, nuclear, and petrochemical industries. Seattle, Washington, USA. April 3-5, 2018. V001T01A005. ASME. https://doi.org/10.1115/ ETAM2018-6741 (2).

3. Wilson AS. Formation and effect of topologically closepacked phases in nickel-based superalloys. Mater Sci Technol. 2017;33(9):1108-18. https://doi.org/10.1080/02670836.2016. $1187335(3)$

4. Lu J, Yang Z, Xu S, Zhao H, Gu Y. Oxidation behaviors of Inconel $740 \mathrm{H}$ in air and dynamic steam. High Temp Mater Process (Lond). 2016;35(7):697-704. https://doi.org/10.1515/htmp-2014-0242.

5. Jiang H, Dong J, Zhang M, Zheng L, Yao Z. Oxidation behaviour and mechanism of Inconel $740 \mathrm{H}$ alloy for advanced ultrasupercritical power plants between 1050 and $1170{ }^{\circ} \mathrm{C}$. Oxid Met. 2015;84:61-72. https://doi.org/10.1007/s11085-015-9543-6.

6. Jia Q, Gu D. Selective laser melting additive manufactured Inconel 718 superalloy parts, high-temperature oxidation property and its mechanisms. Opt Laser Technol. 2014;62:161-71. https://doi.org/ 10.1016/j.optlastec.2014.03.008.

7. Vesel A, Drenik A, Elersic K, Mozetic M, Kovac J, Gyergyek T, Stockel J, Varju J, Panek R, Balat-Pichelin M. Oxidation of Inconel 625 superalloy upon treatment with oxygen or hydrogen plasma at high temperature. Appl Surf Sci. 2014;305:674-82. https://doi.org/10.1016/j.apsusc.2014.03.160.

8. Jiang H, Dong J, Zhang M. Oxidation behavior and mechanism of Inconel $740 \mathrm{H}$ alloy for advanced ultra-supercritical power plants between 1050 and $1170{ }^{\circ} \mathrm{C}$. Oxid Met. 2015;84:61-72. https://doi.org/10.1007/s11085-015-9543-6.

9. Winter K-M, Kalucki J, Koshel D. Process technologies for thermochemical surface engineering. Thermochem Surf Eng Steels. 2015. https://doi.org/10.1533/9780857096524.1.141.

10. Shivamurthy RC, Kamaraj M, Nagarajan R, Shariff SM, Padmanabham G. Laser surface modification of steel for slurry erosion resistance in power plants. In: Woodhead Publishing Series in metals and surface engineering, laser surface modification of alloys for corrosion and erosion, 2012, pp. 177-287. https://doi. org/10.1533/9780857095831.2.177.

11. Vissutipitukul $P$, Aizawa T. Wear of plasma-nitrided aluminum alloys. Wear. 2005;259:482-9. https://doi.org/10.1016/j.wear. 2005.02.119.

12. Gupta K, Jain NK, Laubscher R. Surface property enhancement of gears, advanced gear manufacturing and finishing. New York: Academic Press; 2017. p. 167-96. https://doi.org/10.1016/ B978-0-12-804460-5.00006-7.

13. Edrisy A, Farokhzadeh K. Plasma nitriding of titanium alloys, plasma science and technology. Prog Phys States Chem React. 2016. https://doi.org/10.5772/61937.

14. Hirschmann ACO, Silva MM, Moura Neto C, Ueda M, Mello CB, Barboza MJR, Couto AA. Surface modification of Inconel 718 superalloy by plasma immersion ion implantation. In: Ott EA, Groh JR, Banik A, Dempster I, Gabb TP, Helmink R, Liu X, Mitchell A, Sjöberg GP, Wusatowska-Sarnek A, editors. Superalloy 718 and derivatives. Wiley; 2010. pp. 992-1001. https://doi.org/10.1002/9781118495223.ch75.

15. Kovací H, Ghahramanzadeh HASL, Albayrak Ç, Alsaran A, Çelik A. Effect of plasma nitriding parameters on the wear resistance of alloy Inconel 718. Metal Sci Heat Treat. 2016;58:470-4. https://doi.org/10.1007/s11041-016-0037-1.
16. Ling LS, Yin Z, Hu Z, Wang J, Sun BD. Effects of the $\gamma^{\prime \prime}-\mathrm{Ni}_{3} \mathrm{Nb}$ phase on fatigue behavior of nickel-based 718 superalloys with different heat treatments. Materials. 2019;12(23):3979. https:// doi.org/10.3390/ma12233979.

17. Fournier D, Pineau A. Low cycle fatigue behavior of Inconel 718 at $298 \mathrm{~K}$ and $823 \mathrm{~K}$. Metall Trans A. 1977;8:1095-105. https://doi.org/10.1007/BF02667395.

18. Kukla D, Sitek R. Influence of aluminide layer on the dynamics of the development of fatigue damage in Ni-Cr-Co alloy. Solid State Phenom. 2016;240:101-7. https://doi.org/10.4028/www. scientific.net/SSP.240.101.

19. Kopec M, Kukla D, Yuan X, Rejmer W, Kowalewski ZL, Senderowski C. Aluminide thermal barrier coating for high temperature performance of MAR 247 nickel based superalloy. Coatings. 2021;11:48. https://doi.org/10.3390/coatings 11010048.

20. Genel K, Demirkol MT, Çapa M. Effect of ion nitriding on fatigue behaviour of AISI 4140 steel. Mater Sci Eng A. 2000;279:207-16. https://doi.org/10.1016/S0921-5093(99) 00689-9.

21. Terent'ev VF, Michugina MS, Kolmakov AG, Kvedaras V, Čiuplys V, Čiuplys A, Vilys J. The effect of nitriding on fatigue strength of structural alloys. Mechanika. 2007;2(64):12-22.

22. Sitek R, Kaminski J, Mizera J. Corrosion resistance of the Inconel $740 \mathrm{H}$ nickel alloy after pulse plasma nitriding at a frequency of 10 kHz. Acta Phys Pol, A. 2016;129:584-7. https://doi.org/10.12693/ APhysPolA.129.584.

23. de Castro MCB, Couto AA, Almeida GFC, Massi M, de Lima NB, da Silva-Sobrinho A, Castagnet M, Xavier GL, Oliveira RR. The effect of plasma nitriding on the fatigue behavior of the Ti-6Al4V alloy. Materials. 2019;12:520. https://doi.org/10.3390/ma120 30520.

24. Yamane K, Morino K, Kawagoishi N, Fukada K. Fatigue properties of radical nitrided alloy 718 at elevated temperature under push pull loading. J Soc Mater Sci Jpn. 2010;59:821-6. https:// doi.org/10.2472/jsms.59.821.

25. Fuentes GG. Surface engineering and micro-manufacturing. In: Micro and nano technologies, micromanufacturing engineering and technology; 2015. pp. 459-486. https://doi.org/10.1016/B9780-323-31149-6.00020-7.

26. Xue L, Wang J, Li L, Chen G, Sun L, Yu S. Enhancement of wear and erosion-corrosion resistance of Inconel 718 alloy by liquid nitriding. Mater Res Express. 2020. https://doi.org/10.1088/20531591/abb426.

27. Maniee A, Mahboubi F, Soleimani R. Improved hardness, wear and corrosion resistance of Inconel 718 treated by hot wall plasma nitriding. Met Mater Int. 2020;26:1664-70. https://doi.org/10. 1007/s12540-019-00476-z.

28. Zhang H, Qin H, Ren Z, Zhao J, Hou X, Doll GL, Dong Y, Ye Ch. Low-temperature nitriding of nanocrystalline Inconel 718 alloy. Surf Coat Technol. 2017;330:10-6. https://doi.org/10.1016/j.surfc oat.2017.09.040.

29. Borowski T, Brojanowska A, Kost M, Garbacz H, Wierzchoń T. Modifying the properties of the Inconel 625 nickel alloy by glow discharge assisted nitriding. Vacuum. 2009;83(12):1489-93. https://doi.org/10.1016/j.vacuum.2009.06.056.

30. Pilarska M, Frączek T, Maźniak K. The role of complementary potential in plasma nitriding processes of technical titanium. Arch Metall Mater. 2018;63(4):1637-42. https://doi.org/10.24425/ amm.2018.125087.

Publisher's Note Springer Nature remains neutral with regard to jurisdictional claims in published maps and institutional affiliations. 